\title{
Prognostic Significance of the Glasgow Prognostic Score in Patients Undergoing Pulmonary Metastasectomy
}

\author{
Ulas KUMBASAR ${ }^{1}$, Melih OZERCAN ${ }^{1}$, Sevilay KARAHAN² Erkan DIKMEN $^{1}$, \\ Metin DEMIRCIN ${ }^{1}$, Riza DOGAN ${ }^{1}$ \\ ${ }^{1}$ Hacettepe University Faculty of Medicine Department of Thoracic Surgery \\ ${ }^{2}$ Hacettepe University Faculty of Medicine Department of Biostatistics, Ankara, TURKEY
}

\begin{abstract}
Pulmonary metastasectomy is considered the standard treatment for various cancer types when the primary tumour is under control. The Glasgow Prognostic Score (GPS), which is determined by serum levels of C-reactive protein (CRP) and albumin, is found to be a potential prognostic tool for variable primary cancer types. The aim of this study is to evaluate the prognostic role of the GPS in patients undergoing pulmonary metastasectomy for different subgroups of cancer types. Data of 142 patients who underwent pulmonary metastasectomy at in a single institution were retrospectively analyzed from a prospectively collected database. Primary tumour histologic subtypes were classified into five categories: Gastrointestinal tumours (Colorectal, gastric and colangiocellular carcinomas, $n=43$ ), sarcomas (osteosarcoma, chondrosarcoma and synovial sarcoma, $n=38$ ), breast carcinoma $(n=16)$, genitourinary system carcinomas (Cervix and endometrium carcinomas, $n=10$ ) and miscellaneous $(n=35)$. High GPS is found to be correlated with worse survival rates in the subgroups of pulmonary metastasectomy for gastrointestinal, genitourinary and miscellaneous cancers ( $p=0.050$, $p=0.046$ and $p=0.003$, respectively). Although there is an evident decline of mean survival in breast cancer and sarcoma patients, the effect of GPS score on overall survival was statistically insignificant ( $p=0.081$ and $p=0.056$, respectively). In conclusion, GPS appears to be a useful predictor of overall survival in pulmonary metastases for the majority of cancer types.
\end{abstract}

Key Words: Pulmonary metastasectomy, Survival, GPS

\section{ÖZET}

Pulmoner Metastazektomi Uygulanan Hastalarda Glasgow Prognostik Skoru'nun Prognostic Önemi

Primer tümörün kontrol altında olduğu izole akciğer metastazı bulunan birçok kanser türünde pulmoner metastazektomi standart tedavi olarak kabul edilir. Glasgow prognostik skoru (GPS) serumdaki C-reaktif protein ve albümin değerleri arasındaki ilişki ile elde edilir ve bazı primer kanser türleri için potansiyel bir prognostik faktördür. Bu çalışmanın amacı, bazı kanser türlerinde pulmoner metastazektomi uygulanan hastalarda GPS skorunun prognostik rolünü incelemektir. Bu amaçla, pulmoner metastazektomi uygulanmış olan toplam 142 hastanın verileri retrospektif olarak incelendi. Hastalar primer tümörlerinin histolojik tiplerine göre beş gruba ayrıld: Gastrointestinal tümörler (Kolorektal, gastrik ve kolanjiyoselüler karsinomlar, $n=43$ ), sarkomlar (Osteosarkom, kondrosarkom ve sinoviyal sarkom, $n=$ 38), meme karsinomu ( $n=16$ ), genitoüriner sistem karsinomları (Serviks ve endometriyum, $n=10$ ) ve mikst karsinomlar grubu ( $n=35$ ). GIS, GÜS ve mikst karsinomlu hastalarda GPS skorunun yüksekliği ile kötü sağkalım arasındaki ilişki istatistiksel olarak anlamlı bulundu (sırası ile $p=0.05, p=0.046$ ve $p=0.03$ ). Sarkom ve meme karsinomu gruplarında ise GPS skoru yüksek olan hastaların prognozunun daha kötü olduğu saptanmasına rağmen ilişki istatistiksel olarak anlamlı bulunmadı (sırası ile $p=0.056$ ve $p=0.081$ ). Sonuç olarak, GPS skoru birçok kanser türünde metastatik akciğer kanserlerinin sağkalımını değerlendirmek amacıyla potansiyel prognostik bir belirteç olarak kullanılabilir.

Anahtar Kelimeler: Metastazektomi, Sağkalım, GPS 


\section{INTRODUCTION}

Pulmonary metastasectomy has evolved to become a standard treatment for selected patients in various cancer types when the primary tumour is under control. After resection for primary lung cancer, it is the next most commonly performed major operation in thoracic surgical practice. ${ }^{1}$ Nevertheless, when compared with the primary malignancies, there are only a few prognostic biomarkers currently recommended for routine usage in patients undergoing pulmonary metastasectomy..$^{2-4}$

In recent times, researchers have focused on the prognostic role of systemic inflammation scores in various types of cancer. The Glasgow Prognostic Score (GPS) is such an inflammation based score which is used as a prognostic tool for variable primary cancer types. ${ }^{5}$ GPS is determined by serum levels of C-reactive protein (CRP) and albumin and classified into three groups according to the combination of the standard thresholds of these acute phase proteins. ${ }^{5,6}$

In this study, we aimed to evaluate the prognostic role of the GPS in patients undergoing pulmonary metastasectomy for different subgroups of cancer types.

\section{PATIENTS AND METHODS}

Between January, 2002 and June, 2012, 172 patients who underwent pulmonary metastasectomy at our institutions were retrospectively analyzed from a prospectively collected database. The study was approved by the ethical committee of Hacettepe University Medical Faculty (Non-invasive research ethical committee no: GO-17/471; 30.05.2017). Inclusion criteria were resectability of all pulmonary matatases, absence of extrapulmonary disease and a controlled primary tumour site. We excluded 30 patients because of loss to follow-up, leaving 142 patients for analysis. We were able to calculate GPS of 130 patients due to a lack of preoperative CRP or albumin measurements.

Patients' data were collected including the following variables: sex, age, preoperative serum albumin and CRP levels, primary tumour histologic subtype, chemotherapy before metastasectomy, side and type of the resection (anatomical resec- tions or wedge) and radicality of the resection. Survival status was determined from the date of last follow-up. Mortality status was documented from patient records and the National Health Service database. All serum measurements were performed at a single laboratory and values obtained within one month before surgery were accepted as preoperative levels. Primary tumour histologic subtypes were classified into five categories: Gastrointestinal tumours (Colorectal, gastric and colangiocellular carcinomas, $n=43$ ), sarcomas (osteosarcoma, chondrosarcoma and synovial sarcoma, $\mathrm{n}=38)$, breast carcinoma $(\mathrm{n}=16)$, genitourinary system carcinomas (Cervix and endometrium carcinomas, $n=10)$ and miscellaneous $(n=35)$. Renal cell, testicular and adenoid cystic carcinomas are combined in the miscellaneous group as there are limited number of cases within each type and as they have relatively similar long-term survival rates. The GPS was calculated by using previously allocated threshold values; patients with CRP levels $<1 \mathrm{mg} / \mathrm{dl}$ and albumin levels $>3.5 \mathrm{~g} / \mathrm{dl}$ were assigned as GPS 0 , patients with either high CRP levels $(>1 \mathrm{mg} / \mathrm{dl})$ or low albumin levels $(<3.5 \mathrm{~g} /$ dl) were assigned to GPS 1 and patients with both high CRP levels (>1 mg/dl) and low albumin levels $(<3.5 \mathrm{~g} / \mathrm{dl})$ were assigned to GPS., ${ }^{2,5}$

\section{Statistical Analysis}

Statistical analysis was done using IBM SPSS for Windows (Version 22.0). Continuous data were expressed as mean \pm standard deviation when distribution was normal or as median for data without normal distribution. Groups were compared for continuous variables using Kruskal-Wallis test. Chi square test was used to evaluate differences in categorical variables between groups. Survival curves were obtained using Kaplan Meier product limit estimation method. Survival curves of different groups were compared using log-rank test. A p value below 0.05 was considered significant.

\section{RESULTS}

From the 142 patients included, 86 (60.6\%) were male and $56(39.4 \%)$ were female. The median age was 52 years (range, 19 to 92 ). The clinicopatho- 


\begin{tabular}{|ll|}
\hline Table 1. Patient characteristics & \\
\hline Characteristics & N, \% \\
\hline Sex & \\
Male & $86(60.6)$ \\
Female & $56 / 39.4)$ \\
Metastasectomy side & \\
Right & $79(55.6)$ \\
Left & $55(38.7)$ \\
Bilateral & $8(5.7)$ \\
Type of resection & \\
Anatomical resection & $14(9.8)$ \\
Wedge resection & $128(90.2)$ \\
Histologic subtype & \\
Gastrointestinal system carcinoma & $43(30.2)$ \\
Sarcoma & $38(26.8)$ \\
Breast carcinoma & $16(11.3)$ \\
Testicular carcinoma & $16(11.3)$ \\
Renal cell carcinoma & $12(8.4)$ \\
Genitourinary system carcinoma & $10(7.0)$ \\
Adenoid cystic carcinoma & $7(4.9)$ \\
& \\
\hline
\end{tabular}

logic features of the patients are summarized in Table 1. The patients' characteristics including, age, sex, adjuvant chemotherapy rate, type of resection performed and completeness of the resection were statistically similar among GPS groups. Table 2 shows the patients' characteristics according to the GPS.
The 5-year overall survival (OS) rates for gastrointestinal carcinomas, sarcomas, breast carcinoma, testicular carcinoma, renal cell carcinoma, genitourinary system carcinomas and adenoid cystic carcinoma were $35.7 \%, 52.5 \%, 43.8 \%, 75 \%, 75 \%$, $44.4 \%$ and $85.7 \%$, respectively $(\mathrm{p}=0.019)$. The mean survival rates of underlying tumor types according to GPS are shown in Table 3. The KaplanMeier estimates of the 5-year survival functions among histologic subgroups according to the GPS is shown in Figure 1. The survival curves based on the GPS groups are clearly separated from each other in each histologic subgroup. However, solely in gastrointestinal, genitourinary and miscellaneous groups this separation is statistically important $(\mathrm{p}=0.050, \mathrm{p}=0.046$ and $\mathrm{p}=0.003$, respectively).

\section{DISCUSSION}

In this study, GPS was identified as an independent prognostic factor in various types of pulmonary metastases. There is an increasing trend of pulmonary metastasectomy as part of a concept of individualized treatment for advanced cancer. Pulmonary system is the next most common site of metastases after the liver. In recent practice, colorectal cancer and sarcomas are the most common primary tumors for which pulmoary metastasectomy is performed. Breast, gynaecological, urological, upper gastrointestinal, thyroid and kidney

\begin{tabular}{|c|c|c|c|c|}
\hline & GPS 0 & GPS 1 & GPS 2 & $P$ value \\
\hline \multicolumn{5}{|l|}{ Number (\%) } \\
\hline Patients & $82(63.0)$ & $38(29.1)$ & $10(7.7)$ & \\
\hline \multicolumn{5}{|l|}{ Patient characteristics } \\
\hline Age (median) & 54 & 53 & 56 & 0.787 \\
\hline Sex & & & & 0.084 \\
\hline Male & $48(58.5)$ & $24(63.2)$ & $10(100)$ & \\
\hline Female & $34(41.5)$ & $14(36.8)$ & $0(0)$ & \\
\hline Adjuvant chemotherapy & $58(76.3)$ & $28(73.3)$ & $8(80)$ & 0.951 \\
\hline Type of resection & & & & 0.457 \\
\hline Anatomical & $10(12.1)$ & $2(5.2)$ & $0(0)$ & \\
\hline Wedge & $72(87.9)$ & $36(94.8)$ & $10(100)$ & \\
\hline Completeness of resection & & & & 0.792 \\
\hline Yes & 62 (81.6) & $28(73.7)$ & $8(80)$ & \\
\hline No & $14(18.4)$ & $10(26.3)$ & $2(20)$ & \\
\hline
\end{tabular}


Table 3. The mean survival rates of histologic subgroups according to GPS

\begin{tabular}{|lllll|}
\hline Mean survival (months) \pm SE & GPS 0 & GPS 1 & GPS 2 & P value \\
\hline Histologic subtype & & & & 0.050 \\
$\quad$ Gastrointestinal Ca & $86.3 \pm 15$ & $40.8 \pm 12.6$ & $28.0 \pm 10.0$ & 0.056 \\
Sarcoma & $96.9 \pm 14.2$ & $41.0 \pm 19.5$ & $38.0 \pm 0.0$ & 0.081 \\
Breast Ca & $109.7 \pm 23.2$ & $38.5 \pm 21.7$ & $5.0 \pm 0.0$ & 0.046 \\
Genitourinary system Ca & $84.2 \pm 29.2$ & $9.0 \pm 0.0$ & & 0.003 \\
Miscellaneous Ca & $157.1 \pm 15.3$ & $125 \pm 23.8$ & $5.0 \pm 0.0$ & \\
\hline Ca: Carcinoma & & & & \\
\hline
\end{tabular}

cancers mostly appear in mixed series due to their limited numbers. ${ }^{1,7,8}$

The five-year survival rates of pulmonary metastasectomy ranges widely between $20 \%$ to $70 \%$ depending on several clinical factors such as histology of the primary tumour, resectability, disease free period and the number of metastatic nodules. ${ }^{1,9}$ However, the clinical and biological determinants of postsurgical outcome are not completely elucidated and reliable predictors of long-term survival are still controversial. ${ }^{10,11}$

Up to date, an increasing interest is being devoted to the prognostic role of systemic inflammation scores such as neutrophil-to-lymphocyte ratio (NLR), platelet-to-lymphocyte ratio (PLR) and Creactive protein in surgical oncology. ${ }^{5,6,12,13}$ In this report we targeted on the GPS which is such an inflammation based score that is used as a prognostic tool for variable primary cancer types.

The role of inflammatory markers on cancer survival is based on the concept of increasing host systemic inflammatory response which is critical in the development and progression of many cancers. Growth of cancer cells and their invasion to local tissues provokes a systemic acute-phase response. In addition, proinflammatory cytokines which are released from cancer cells triggers the immunologic system and cause an increase in CRP, albumin, neutrophil, platelet and lymphocyte levels. ${ }^{5,14-16}$ The first study regarding the role of GPS on cancer survival was conducted by Proctor et al. They addressed a positive correlation between increasing GPS and reduced cancer-specific survival in all cancers. ${ }^{17}$ Other authors also validated their results with different types of cancers. ${ }^{5,15,18-20} \mathrm{Nev}$ ertheless, all these studies were conducted on spe- cial subgroup of patients such as inoperabl primary lung cancer patients or metastatic colorectal cancer patients. Recently, Kawashima et al. analysed 1043 lung cancer patients who underwent resection and reported GPS as a useful prognostic indicator of the overall survival in lung cancer surgery. Miyazaki et al. also advocated the usage of GPS as a simple prognostic tool for elderly patients with clinical stage I non-small-cell lung cancer patients. ${ }^{12,13}$

The aim of our study was to investigate GPS in different subtypes of metastatic cancer. We think that GPS is more reliable in patients with metastatic diseases due to more advanced disease of these patients. For this purpose we subdivided the patients who had undergone metastatectomy according to their primary cancer types. Due to the limited number of cases we consolidated some subgroups into one single group of cancer type. We also combine rare tumors such as renal cell, testicular and adenoid cystic carcinomas which also have relatively similar long-term survival rates in the miscellaneous group. We demonstrated that high GPS is associated with worse survival rates solely in the subgroups of pulmonary metastasectomy for gastrointestinal, genitourinary and miscellaneous cancers $(\mathrm{p}=0.050, \mathrm{p}=0.046$ and $\mathrm{p}=0.003$, respectively). Although there is an evident decline of mean survival in breast cancer and sarcoma patients, it was found to be statistically insignificant ( $\mathrm{p}=0.081$ and $\mathrm{p}=0.056$, respectively).

The assessment of the GPS includes solely albumin and CRP levels which are inexpensive and available in the coverage of routine laboratory data. In addition, the calculation of the GPS is straightforward and can be judged quickly. Thus, utilization of the GPS in routine assessment of cancer patients is very practical. 




Figure 1. The Kaplan-Meier estimates of the 5-year survival functions among histologic subgroups according to the GPS

There are some limitations in this study. This is a retrospective study conducted at a single institution and the sample population was quite small in some subgroups which may affect statistical accuracy. Thus, future studies are needed to address these limitations and to evaluate the use of the GPS in clinical practice.

In conclusion, to the best of our knowledge, this is the first study to evaluate the prognostic role of GPS in various types of pulmonary metastases and we demonstrated that GPS appears to be a useful predictor of overall survival in pulmonary metastases for the majority of cancer types. However, our data deserve further verification with multi-center and larger scale prospective trials.

\section{REFERENCES}

1. Treasure T, Milosevic M, Fiorentino F, Macbeth F. Pulmonary metastasectomy: what is the practice and where is the evidence for effectiveness? Thorax 69: 946-949, 2014.

2. Mineo TC, Tacconi F. Role of systemic inflammation scores in pulmonary metastasectomy for colorectal cancer. Thorac Cancer 5: 431-437, 2014.
3. Schweiger T, Lang G, Klepetko W, Hoetzenecker K. Prognostic factors in pulmonary metastasectomy: spotlight on molecular and radiological markers. Eur J Cardiothorac Surg 45: 408-416, 2014.

4. Ghanim B, Schweiger T, Jedamzik J, et al. Elevated inflammatory parameters and inflammation scores are associated with poor prognosis in patients undergoing pulmonary metastasectomy for colorectal cancer. Interact Cardiovasc Thorac Surg 21: 616-623, 2015.

5. McMillan DC. The systemic inflammation-based Glasgow Prognostic Score: a decade of experience in patients with cancer. Cancer Treat Rev 39: 534-540, 2013.

6. Leitch EF, Chakrabarti M, Crozier JE, et al. Comparison of the prognostic value of selected markers of the systemic inflammatory response in patients with colorectal cancer. British journal of cancer 97: 1266-1270, 2007.

7. Hofmann HS, Neef H, Krohe K, et al. Prognostic factors and survival after pulmonary resection of metastatic renal cell carcinoma. Eur Urol 48: 77-81, 2005.

8. Welter $\mathrm{S}$, Jacobs $\mathrm{J}$, Krbek $\mathrm{T}$, et al. Pulmonary metastases of breast cancer. When is resection indicated? Eur $\mathrm{J}$ Cardiothorac Surg 34: 1228-1234, 2008.

9. Pastorino $U$, Buyse $M$, Friedel $G$, et al. Long-term results of lung metastasectomy: prognostic analyses based on 5206 cases. J Thorac Cardiovasc Surg 113: 37-49, 1997. 
10. Suzuki M, Iwata T, Ando S, et al. Predictors of long-term survival with pulmonary metastasectomy for osteosarcomas and soft tissue sarcomas. J Thorac Cardiovasc Surg 47: 603608, 2006.

11. Chen F, Miyahara R, Bando T, et al. Prognostic factors of pulmonary metastasectomy for osteosarcomas of the extremities. Eur J Cardiothorac Surg 34: 1235-1239, 2008.

12. Kawashima M, Murakawa T, Shinozaki T, et al. Significance of the Glasgow Prognostic Score as a prognostic indicator for lung cancer surgery. Interact Cardiovasc Thorac Surg 21: 637-643, 2015.

13. Miyazaki T, Yamasaki N, Tsuchiya T, et al. Inflammationbased scoring is a useful prognostic predictor of pulmonary resection for elderly patients with clinical stage I non-smallcell lung cancer. Eur J Cardiothorac Surg 47: e140-5, 2015.

14. Hwang EC, Hwang IS, Yu HS, et al. Utility of inflammationbased prognostic scoring in patients given systemic chemotherapy first-line for advanced inoperable bladder cancer. Jpn J Clin Oncol 42: 955-960, 2012.

15. Leung EY, Scott HR, McMillan DC. Clinical utility of the pretreatment glasgow prognostic score in patients with advanced inoperable non-small cell lung cancer. J Thorac Oncol 7: 655-662, 2012.

16. Templeton AJ, McNamara MG, Seruga B, et al. Prognostic role of neutrophil-to-lymphocyte ratio in solid tumors: a systematic review and meta-analysis. J Natl Cancer Inst 106: 124-126, 2014.
17. Proctor MJ, Morrison DS, Talwar D, et al. An inflammationbased prognostic score (mGPS) predicts cancer survival independent of tumour site: a Glasgow Inflammation Outcome Study. British journal of cancer 104: 726-734, 2011.

18. Dreanic J, Maillet M, Dhooge M, et al. Prognostic value of the Glasgow Prognostic Score in metastatic colorectal cancer in the era of anti-EGFR therapies. Med Oncol 30: 656-660, 2013.

19. Fukuchi M, Kuwabara $K$, Tsuji $Y$, et al. C-reactive protein is a negative independent factor in patients with stage IV colorectal cancer undergoing oxaliplatin-based chemotherapy. Anticancer research 33: 5051-5055, 2013

20. Inoue $\mathrm{Y}$, Iwata $\mathrm{T}$, Okugawa $\mathrm{Y}$, et al. Prognostic significance of a systemic inflammatory response in patients undergoing multimodality therapy for advanced colorectal cancer. Oncology 84: 100-107, 2013

\section{Correspondence:}

Dr. Ulas KUMBASAR

Hacettepe Üniversitesi Tip Fakultesi

Gögüs Cerrahisi Anabilim Dali

Sihhiye, ANKARA / TURKEY

Tel: (+90-312) 3051774

e-mail: ulaskumbasar@gmail.com 